\title{
GRAPHIC COMMUNICATION \\ for TECHNICAL DESIGN
}




\section{GRAPHIC COMMUNICATION for \\ TECHNICAL DESIGN}

K. Simms, B.Sc., C.Eng. M. I.Prod.E. 


\section{(C) K. Simms 1981}

All rights reserved. No part of this publication may be reproduced or transmitted, in any form or by any means, without permission

First published 1981 by

THE MACMILLAN PRESS LTD

London and Basingstoke

Associated companies in Delhi Dublin

Hong Kong Johannesburg Lagos Melbourne

New York Singapore and Tokyo

ISBN 978-0-333-29181-8 ISBN 978-1-349-05536-4 (eBook)

DOI 10.1007/978-1-349-05536-4

Typeset by Illustrated Arts

The paperback edition of this book is sold subject to the condition that it shall not, by way of trade or otherwise, be lent, resold, hired out, or otherwise circulated without the publisher's prior consent in any form of binding or cover other than that in which it is published and without a similar condition including this condition being imposed on the subsequent purchaser 


\section{CONTENTS}

$\begin{array}{lr}\text { 1. Basic Information and Constructions } & 1\end{array}$

$\begin{array}{ll}\text { 2. Orthographic Projection } & 36\end{array}$

$\begin{array}{lr}\text { 3. Isometric and Oblique Drawing } & 59\end{array}$

4. Auxiliary Projection $\quad 84$

$\begin{array}{ll}\text { 5. Sections, Intersections and Developments } & 110\end{array}$

$\begin{array}{lr}\text { 6. Loci } & 151\end{array}$

$\begin{array}{ll}\text { 7. Isometric, Axonometric and Perspective Projection } & 184\end{array}$

8. Engineering Drawing Notes and Exercises 200 


\section{PREFACE}

In order to communicate ideas on design the engineer makes use of drawings, in either pictorial or orthographic projection, which is really the common language of the technologist, draughtsman or design engineer. Hence, in the title 'Graphic Communication for Technical Design' there is the connotation of a language - a common language - which may be understood by anyone who takes the trouble to learn the simple principles of its translation.

The order of treatment of the various topics is logical and progressive, ranging from simple basic geometrical constructions to preparation of the various types of pictorial projections and engineering drawing assemblies in orthographic projection. This self tutoring style work course has been class room tested for some years and in the opinion of the author forms an ideal basic course for use with pupils of mixed ability who may be studying for different examinations. The latest drawing office standards are used and emphasised throughout the work.

Both first and third angle systems of orthographic projection have been freely used in view of the fact that there is still no firm ruling from standards authorities for the adoption of one universal system. From the educational point of view the author believes that the student should be encouraged to become competent in either system of projection. The word 'view' has been employed in place of the word 'elevation', in keeping with the latest trend, except in the chapter on Auxiliary Projection where the use of the word 'view' could lead to some confusion.

The basic graphic communication topics have been treated adequately for the examinations already mentioned. In fact some topics have been taken a stage further, to add interest and to cater for the more able student who may have in mind more advanced work in technical design.

I wish to thank the engineering firms who kindly supplied photographs and permission to use diagrams, for which acknowledgement is given in the text. I also wish to thank the NI Schools Examinations Council for permission to use examination questions as indicated.

K. Simms 